\title{
FIRST RECORD OF IXODES ARIADNAE IN GERMANY - SHORT COMMUNICATION
}

\author{
Sándor HORNOK ${ }^{1 *}$, Nóra TAKÁCS ${ }^{1}$, Krisztina SzÖKE ${ }^{1}$ and Bernd KUNZ ${ }^{2}$ \\ ${ }^{1}$ Department of Parasitology and Zoology, Faculty of Veterinary Science, \\ Szent István University, István u. 2, H-1078 Budapest, Hungary; \\ ${ }^{2}$ Hauptstraße 111, D-74595 Langenburg, Germany
}

(Received 23 April 2015; accepted 22 June 2015)

\begin{abstract}
A long-legged tick was collected from a hibernating greater mouse-eared bat (Myotis myotis) in Baden-Württemberg, Germany. Based on morphological characteristics as well as on partial COI and 16S rDNA gene sequences the tick was identified as an engorged female of Ixodes ariadnae. The greater mouseeared bat is a new host record for this tick species. Taking into account the geographical position of the collection site and the known migration distance of the greater mouse-eared bat, the present data suggest the autochthonous occurrence of I. ariadnae in Germany. This is the first record of I. ariadnae in Germany, and in any country other than Hungary, where this species has been recently discovered.
\end{abstract}

Key words: Bat, tick, Ixodes, Myotis

Bats are increasingly recognised as eco-epidemiologically important mammals, in part because many species live in human settlements, even in buildings. In such places humans may be exposed to bites of bat ectoparasites, most importantly of ticks (Jaenson et al., 1994; Estrada-Pena and Jongejan, 1999; Piksa et al., 2013). Bat ticks were shown to carry zoonotic pathogens, including rickettsiae, borreliae, ehrlichiae (Socolovschi et al., 2012) and bartonellae (Hornok et al., 2012).

For more than a century, only two species of ixodid ticks were known to infest bats in Europe, the long-legged bat tick (Ixodes vespertilionis) and I. simplex (Nosek and Sixl, 1972). However, recently a new long-legged species, I. ariadnae has been discovered (Hornok et al., 2014a). The three ixodid bat tick species appear to differ in their host preferences, i.e. I. vespertilionis occurs predominantly on Rhinolophus spp. (Piksa et al., 2014), I. simplex on Miniopterus schreibersii (Arthur, 1956), whereas I. ariadnae was found on Plecotus auritus and Myotis spp. (Hornok et al., 2014a). Thus, the various habitat preferences and hibernating behaviour of bat species will significantly influence the geographical distribution of bat ticks.

*Corresponding author; E-mail: Hornok.Sandor@aotk.szie.hu; Phone: 0036 (1) 478-4187, Fax: 0036 (1) 478-4193 
Despite the fact that $I$. vespertilionis was originally described in Germany (Koch, 1844), it is relatively seldom found on bats (Kulzer and Müller, 2003). One reason for this may be that Rhinolophus spp. became nearly extinct in the country, and their habitats (caves) are restricted. According to literature data $I$. vespertilionis occurs in several locations in Germany, but I. simplex was recorded only from one place (Petney et al., 2012). Here we report the morphological and molecular identification of a long-legged bat tick collected in Germany.

On 6 March 2015 a long-legged tick was removed from a greater mouseeared bat (Myotis myotis), hibernating in a natural cave at the north rim of the river Bühler valley $\left(49.1550^{\circ} \mathrm{N}\right.$ and $9.9272^{\circ} \mathrm{E}$, ca. $400 \mathrm{~m}$ above sea level, northwest of the village Hopfach, Baden-Württemberg, Germany). The collection site is shown in Fig. 1. The authorisation number for bat handling is 558850.68/SHA (issued by the Regierungspräsidium Stuttgart Abteilung Umwelt).

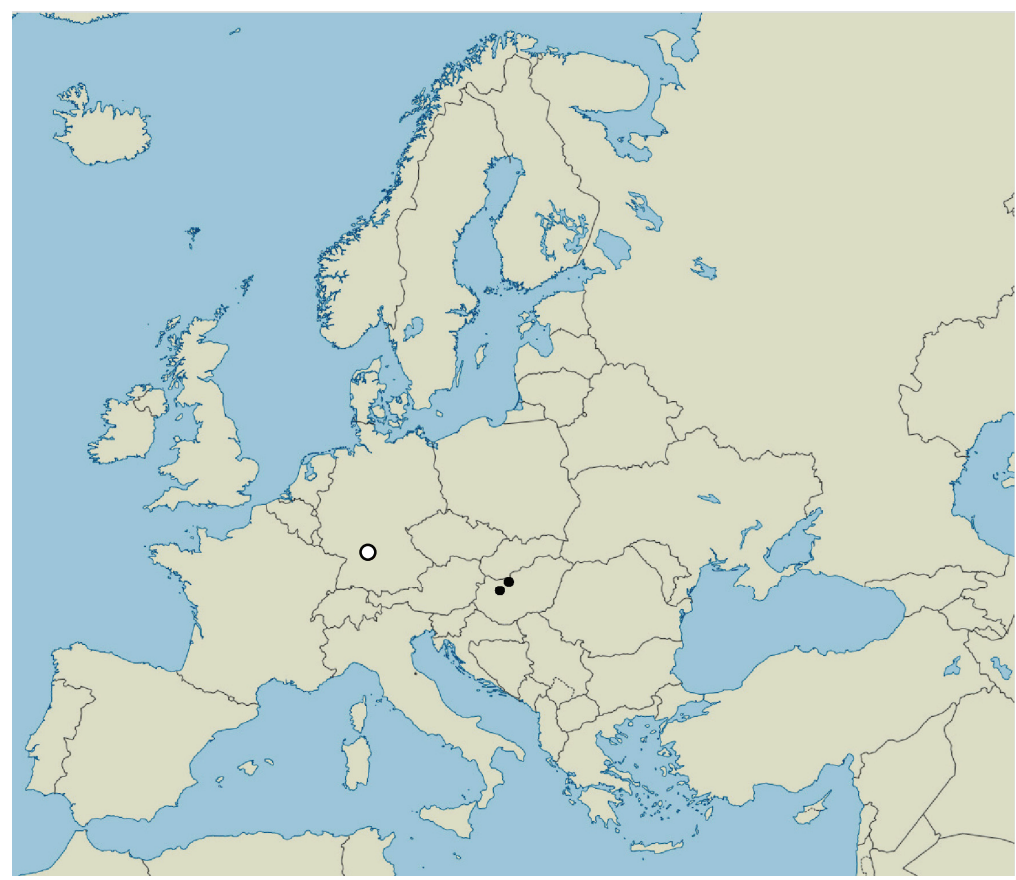

Fig. 1. Map of Europe showing the collection site of Ixodes ariadnae in Germany (white dot) and its formerly reported occurrence in Hungary (black dots)

The tick was stored in $96 \%$ ethanol. Morphological identification was done with a stereomicroscope (SMZ-2T, Nikon Instruments, Japan, illuminated with model 5000-1, Intralux, Switzerland). Molecular analysis was also performed with PCR and sequencing, in order to compare the tick with other tick 
isolates of which relevant data are available in the GenBank. The DNA was extracted from one hind leg of the tick as described (Hornok et al., 2014b).

The cytochrome oxidase subunit I (COI) gene was chosen as the first target for molecular analysis, on account of its suitability as a DNA-barcode sequence for tick species identification. The PCR was modified from Folmer et al. (1994) and amplifies an approx. $710 \mathrm{bp}$ long fragment of the gene. The primers HCO2198 (5'-TAA ACT TCA GGG TGA CCA AAA AAT CA-3') and LCO1490 (5'-GGT CAA CAA ATC ATA AAG ATA TTG G-3') were used in a reaction volume of $25 \mu \mathrm{l}$, containing $1 \mathrm{U}(0.2 \mu \mathrm{l})$ HotStarTaq Plus DNA polymerase, $2.5 \mu \mathrm{l} 10 \times$ CoralLoad Reaction buffer (including $15 \mathrm{mM} \mathrm{MgCl}{ }_{2}$ ), $0.5 \mu \mathrm{l}$ PCR nucleotide Mix ( $0.2 \mathrm{mM}$ each), $0.5 \mu \mathrm{l}(1 \mu \mathrm{M}$ final concentration) of each primer, $15.8 \mu 1 \mathrm{ddH}_{2} \mathrm{O}$ and $5 \mu \mathrm{l}$ template DNA. For amplification, an initial denaturation step at $95^{\circ} \mathrm{C}$ for $5 \mathrm{~min}$ was followed by 40 cycles of denaturation at $94{ }^{\circ} \mathrm{C}$ for $40 \mathrm{~s}$, annealing at $48^{\circ} \mathrm{C}$ for $1 \mathrm{~min}$ and extension at $72{ }^{\circ} \mathrm{C}$ for $1 \mathrm{~min}$. Final extension was performed at $72{ }^{\circ} \mathrm{C}$ for $10 \mathrm{~min}$.

Another PCR was used to amplify an approx. $460 \mathrm{bp}$ fragment of the $16 \mathrm{~S}$ rDNA gene of Ixodidae (Black and Piesman, 1994), with the primers 16S+1 (5'CTG CTC AAT GAT TTT TTA AAT TGC TGT GG-3') and 16S-1 (5'-CCG GTC TGA ACT CAG ATC AAG T-3'). Other reaction components, as well as cycling conditions were the same as above, except for annealing at $51^{\circ} \mathrm{C}$.

PCR products were electrophoresed in a $1.5 \%$ agarose gel $(100 \mathrm{~V}, 60 \mathrm{~min})$, stained with ethidium bromide and visualised under ultraviolet light. Purification and sequencing was done by Biomi Inc. (Gödöllö, Hungary). The sequences were submitted to the GenBank (accession numbers KR093169 and KR093170, respectively).

Based on morphological characteristics, i.e. $5 \mathrm{~mm}$ size, long legs, short palps, broad and posteriorly rounded scutum (Fig. 2) and sparse covering with setae, the tick was identified as an engorged female of I. ariadnae. The greater mouse-eared bat (M. myotis), from which the specimen was collected, is a new host record for this tick species.

The partial COI sequence of the tick (KR093169) showed 100\% homology with I. ariadnae (KJ490306). The partial 16S rDNA gene sequence of the tick (KR093170) was identical with genotype F among Hungarian isolates, collected at the main habitat of I. ariadnae in Hungary (Ariadne cave system, Pilis Mountains: Hornok et al., 2015).

The collection site of I. ariadnae in Germany is at least $250 \mathrm{~km}$ from the southeastern country borders, and approx. $650 \mathrm{~km}$ from the known habitats of this tick species in Hungary. Taking into account that the tick in the present study was removed from a bat species with migration ranges of approx. $100-250 \mathrm{~km}$ in Germany and Hungary (Griffin, 1970), these data suggest the autochthonous occurrence of I. ariadnae in Germany. 


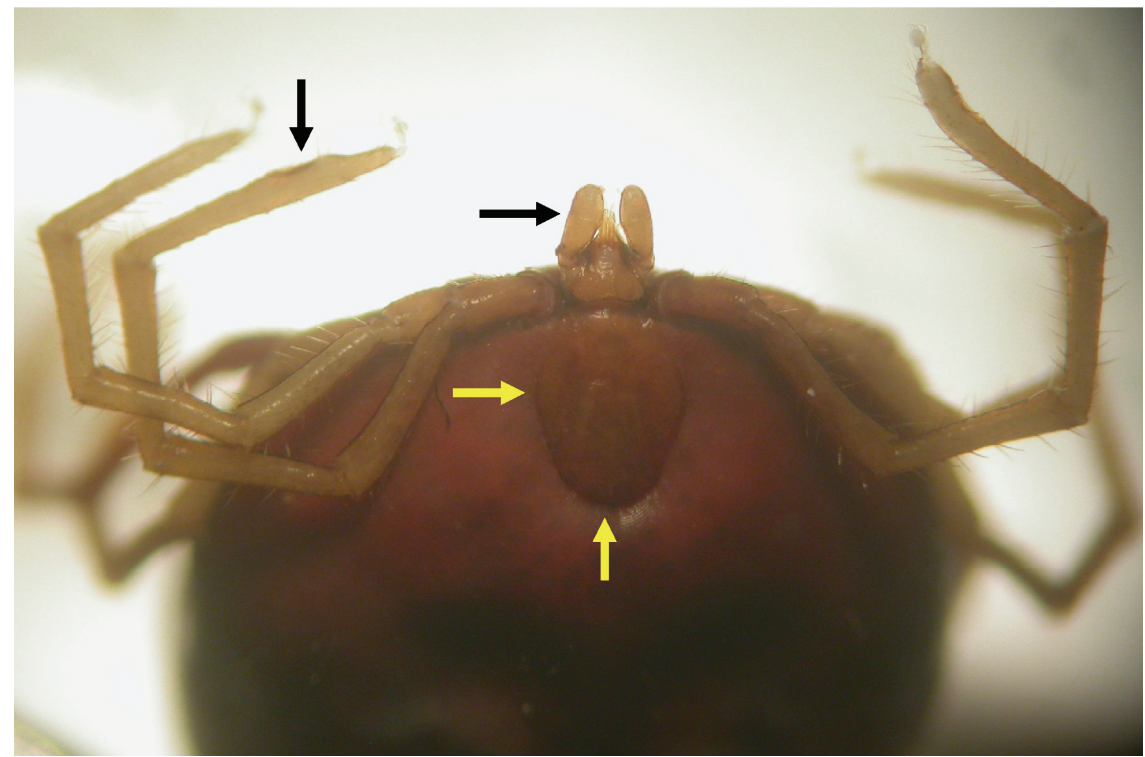

Fig. 2. Anteriodorsal view of the bat tick collected in the present study. Arrows indicate the characteristics of Ixodes ariadnae mentioned in the text

This is the first record of I. ariadnae in Germany, and in any country other than Hungary, where this species has been recently discovered (Hornok et al., 2014a). The tick will be deposited in the Museum für Naturkunde Berlin. In order to ascertain if the present finding represents a unique case, or I. ariadnae has a more widespread occurrence in Germany or the surrounding countries, further bat tick monitoring is recommended.

\section{References}

Arthur, D. R. (1956): The Ixodes ticks of Chiroptera (Ixodoidea, Ixodidae). J. Parasitol. 42, 180-196.

Black, W. C. and Piesman, J. (1994): Phylogeny of hard and soft-tick taxa (Acari: Ixodida) based on mitochondrial 16s rDNA sequences. Proc. Nat. Acad. Sci. USA 91, 10034-10038.

Estrada-Peña, A. and Jongejan, F. (1999): Ticks feeding on humans: a review of records on humanbiting Ixodoidea with special reference to pathogen transmission. Exp. Appl. Acarol. 23, 685-715.

Folmer, O., Black, M., Hoeh, W., Lutz, R. and Vrijenhoek, R. (1994): DNA primers for amplification of mitochondrial cytochrome $\mathrm{C}$ oxidase subunit I from diverse metazoan invertebrates. Mel. Marine Biol. Biot. 3, 294-299.

Griffin, D. R. (1970): Migrations and homing of bats. In: Wimshaft, W. A. (ed.) Biology of Bats. Volume 1. Academic Press, New York. pp. 233-264.

Hornok, S., Kontschán, J., Estrada-Peña, A., Fernández de Mera, I. G., Tomanovic, S. and de la Fuente, J. (2015): Contributions to the morphology and phylogeny of the newly discovered bat tick species, Ixodes ariadnae in comparison with I. vespertilionis and I. simplex. Parasit. Vectors $\mathbf{8}, 47$. 
Hornok, S., Kontschán, J., Kováts, D., Kovács, R., Angyal, D., Görföl, T., Polacsek, Z., Kalmár, Z. and Mihalca, A. D. (2014a): Bat ticks revisited: Ixodes ariadnae sp. nov. and allopatric genotypes of I. vespertilionis in caves of Hungary. Parasit. Vectors 7, 202.

Hornok, S., Kovács, R., Meli, M. L., Kontschán, J., Gönczi, E., Gyuranecz, M., Dán, Á., Molnár, V. and Hofmann-Lehmann, R. (2012): First detection of bartonellae in a broad range of bat ectoparasites. Vet. Microbiol. 159, 541-543.

Hornok, S., Kováts, D., Csörgö, T., Meli, M. L., Gönczi, E., Hadnagy, Z., Takács, N., Farkas, R. and Hofmann-Lehmann, R. (2014b): Birds as potential reservoirs of tick-borne pathogens: first evidence of bacteraemia with Rickettsia helvetica. Parasit. Vectors 7, 128.

Jaenson, T. G., Tälleklint, L., Lundqvist, L., Olsen, B., Chirico, J. and Mejlon, H. (1994): Geographical distribution, host associations, and vector roles of ticks (Acari: Ixodidae, Argasidae) in Sweden. J. Med. Entomol. 31, 240-256.

Koch, C. L. (1844): Systematische Übersicht über die Ordnung der Zecken. Arch. Naturgesch. 10, 232.

Kulzer, E. and Müller, E. (2003): Ektoparasiten der heimischen Fledermäuse. Kursmanuskript der Arbeitsgemeinschaft Fledermausschutz in Baden-Württemberg. 42 pp.

Nosek, J. and Sixl, W. (1972): Central-European Ticks (Ixodoidea). Key for Determination. Jahrbuch der naturwissenschaftlichen Abteilung Joanneum 1/2, 61-92.

Petney, T. N., Pfäffle, M. and Skuballa, J. (2012): An annotated checklist of the ticks of Germany. Syst. Appl. Acarol. 17, 115-170.

Piksa, K., Górz, A., Nowak-Chmura, M. and Siuda, K. (2014): The patterns of seasonal activity of Ixodes vespertilionis (Acari: Ixodidae) on Rhinolophus hipposideros in nursery colonies. Ticks Tick Borne Dis. 5, 69-74.

Piksa, K., Nowak-Chmura, M. and Siuda, K. (2013): First case of human infestation by the tick Ixodes vespertilionis (Acari: Ixodidae). Int. J. Acarol. 38, 1-2.

Socolovschi, C., Kernif, T., Raoult, D. and Parola, P. (2012): Borrelia, Rickettsia, and Ehrlichia species in bat ticks, France, 2010. Emerg. Infect. Dis. 18, 1966-1975. 